\title{
An Exploratory Study of Compensation Mix in Pay Administration System: The Ghanaian Situation
}

Rita Sarkodie Baffoe, Kofi Amponsah -Bediako

To Link this Article: http://dx.doi.org/10.6007/IJARBSS/v11-i12/10907

DOI:10.6007/IJARBSS/v11-i12/10907

Received: 09 October 2021, Revised: 12 November 2021, Accepted: 27 November 2021

Published Online: 19 December 2021

In-Text Citation: (Baffoe \& Bediako, 2021)

To Cite this Article: Baffoe, R. S., \& -Bediako, K. A. (2021). An Exploratory Study of Compensation Mix in Pay Administration System: The Ghanaian Situation. International Journal of Academic Research in Business and Social Sciences, 11(12), 2247-2258.

\section{Copyright: @ 2021 The Author(s)}

Published by Human Resource Management Academic Research Society (www.hrmars.com)

This article is published under the Creative Commons Attribution (CC BY 4.0) license. Anyone may reproduce, distribute, translate and create derivative works of this article (for both commercial and non0-commercial purposes), subject to full attribution to the original publication and authors. The full terms of this license may be seen at: http://creativecommons.org/licences/by/4.0/legalcode

Vol. 11, No. 12, 2021, Pg. 2247- 2258

Full Terms \& Conditions of access and use can be found at http://hrmars.com/index.php/pages/detail/publication-ethics 


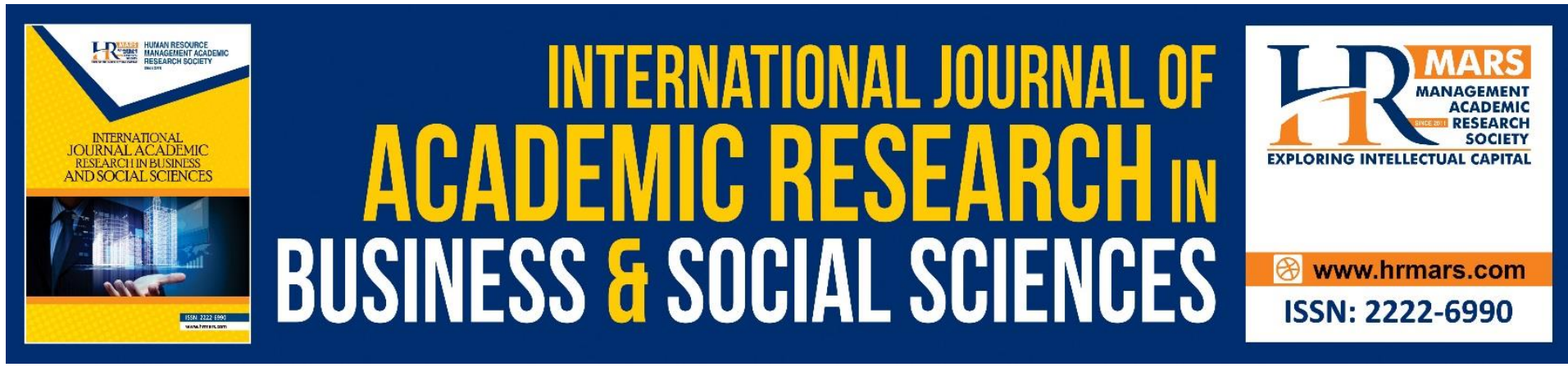

\title{
An Exploratory Study of Compensation Mix in Pay Administration System: The Ghanaian Situation
}

\author{
Rita Sarkodie Baffoe \\ Lecturer, Management and Public Administration Department, Accra Technical University, \\ Ghana.
}

\section{Dr. Kofi Amponsah -Bediako}

Head of Communications, Ghana Standards Board, Accra.

\begin{abstract}
Compensation research has focused on the various forms of pay (financial and non-financial) and structure (relationship between various incentive levels) and whether these incentives contribute to inspiring workers to offer their best results.

There has been less focus on incentive balance choices, i.e. the comparative amounts that make up the complete reward of each factor.

Compensation is a key issue in pay administration and in attracting, retaining and motivating the workforce of every organization. Most Organizations adopt the most equitable within and efficient externally, pay structures to obtain maximum performance from their workers. Less emphasis has been placed on compensation mix decisions by policy makers either because they find the concept to be foreign to the Ghanaian situation or lack the understanding of how to incorporate it in their compensation policy.

Therefore, this paper discusses current literature on the notion of compensation mix and it relevance, applicability and adoption to the Ghanaian situation and seeks to determine whether its applicability will lead to addressing some of the employee perceptions on compensation. The researchers' further outlines strategies it believes could support better employee engagement of workers in Ghana through the adoption of the right compensation mix as a human resource tool in setting pay levels and pay structures and influencing compensation policy.
\end{abstract}

Keywords: Compensation, Compensation Mix, Organizations, Pay and Rewards

\section{Introduction}

Orientation

Compensation has become the critical criteria that influences employees to take up new appointment, remain engaged and motivated in organizations Compensation is the advantage earned by a worker in return for their efforts to the company. It is an integrated system which requires the management of work relationship and the availability of resources and non-monetary benefits to staff. 
(Patnaik \& Padhi, 2012). A worker's success is not largely dependent on his talent, intellect, skills and knowledge, but on the reward and compensation he earns (Armstrong, 2009). This makes the issue of compensation and compensation mix important in employee engagement decisions. The incentive programs encourage workers and are often used to achieve other purposes, such as approved submission, presumed employee fairness, cost management and enhancement (George et al., 2016).

\section{Research Purpose and Objectives}

The aim of this paper is to examine the concept of compensation mix and its applicability to private organizations and how if adopted can be used to attract, encourage and sustain employees for better employee engagement. Rewarding employees for their contribution and value to the organization, has become problematic in managing employees .As employers seek to adopt strategies in their compensation plan by using both monetary and non-monetary rewards to appreciate workers by ensuring better engagement,employees also look out for the best compensation they can obtain through their efforts.A well designed and implemented compensation policy and compensation mix that satisfies employee perception and rewards them effectively can lead to better productivity, motivation, retention and better engagement. There has been several studies done to find out the best way of engaging employees however, further guidance on how organizations can formulate effective incentive strategies, particularly non-financial incentives, is still needed despite these studies (Armstrong \& Stephens, 2005; Schlechter et al., 2015).

In Ghana, these challenges have resulted in labor unrest and low productivity in some instances where worker because of disagreement over pay and other benefits may resort to unproductive behaviors such as lateness, absenteeism, and sabotage all in a bid to reduce productivity due to their dissatisfaction with their compensation package.

Compensation packages provide certain basic features that aim to make workers productive, namely pay, incentives, opportunities, allowances, promotion, appreciation (Obisi, 1996; Werner, 2001).

Hartman (2014) argued that payment scheme should be explicitly communicated to workers through job appraisal schemes in order to prevent misconceived notion and conflict among workers, to generate performance required. Employee perception would be positively influence by the perfect blend of financial and benefits communicated in the way that makes employee feel valued by the organization. Both of these have a huge effect on the efficiency and commitment of workers (Yamoah, 2013).

The effect of globalization, intense competition of manpower due to shortage of some skilled labour in certain sectors of the economy has made the management of employees critical to the success of most organizations .As asserted by George et al (2016 ), company's compensation management is much dynamic today than it used to be about four decades earlier.

Banjoko (2006) explained that, the difficulty could be traced to procedural, personal, economic and cultural pressures that have emerged recently, employees although are concerned of their pay check may not be particular of the blend of both monetary and nonmonetary benefits given by employers and in most cases may never demand to know the amount of their compensation in the compensation plan.

Compensation mix considers the proportion in an employee's salary of monetary and nonmonetary benefits, given to workers. Overall optimal total compensation combination involves financial and non-financial incentives (Pregnolato et al., 2017). 
The essence of the positions and the type of workers who fill them should also be included in the mix of incentive forms (Greene, 2015). Since, compensation influences the quality of the candidates, the quantity of the employees, the likelihood of employment acceptance, the extent of satisfaction and efficiency of the employees, and the quality of those who stay with the organization. (Dineen \& Williamson , 2012; Saks et al., 1996; Shaw \& Gupta , 2007), making it an important component which must be given serious thought in compensation administration.

Increasingly employees are beginning to question the pay given by their employees in terms of how it addresses their particular needs. As succinctly stated by Foot et al , (2016), organizations in their bid to remain competitive in the labor market both locally and globally adopt the best compensation plan which encompasses different mix of compensation and benefits levels necessary to motivate employees and maintain profit at desirable levels to meet shareholder needs. They further suggest that, the system that is adopted, main aspects of the strategic plan must be in line with and endorse them, and companies create pay and compensation plans that match their individual company and the combination of generations of workers within it.

The need for organizations to pay attention to their reward management system has been the focus of most researchers in compensation management administration as averred by Korir \& Kipkebut (2016), in the current complex and competitive climate, incentive management has gained increased significance. This is because it helps companies to hire and retain workers and improve operational efficiency (Dalvi \& Ibrahim, 2013). Datta (2012) argues most businesses consider employees as their primary factor in creating brand benefits in the future.

Reward management includes the policies, practices and decisions made to ensure that the contribution of people in a company is acknowledged through both non- monetary and monetary means. There are different types of incentives; associated incentives, monetary and pay-related, and the advantages a company offers to its workforce and non-monetary benefits; benefits that focus on empowering employees and also enhancing organizational participation and commitment, (Armstrong \& Murlis, 2007).

The technology, diversification, market position and human resource decisions of a company are associated with worker compensation (Balkin \& Gomez-Mejia, 1990; Nickerson \& Zenger, 2008) and have broad implications for the enterprise performance (Gomez-Mejia, 1992).

The compensation package is the financial and non-financial benefits earned by workers in exchange for their energy, abilities, contributions and outcomes (World at Work, 2006, p. 1.5). These total rewards include various compensation forms (base pay, overtime, reward, and incentives), benefits such as medical, insurance, temporary and permanent disability, holiday pay, pension savings, and training.

In addition, Diekmann (2015) asserts that variable hours or telecommuting, success recognition, job growth and work-life balance options are also considered part of overall incentives (p14). Since many companies have issues with employee attraction and retention, managers need to restructure their reward system in order to appreciate their participation and results (De Gieter \& Hofmans, 2015)

Reward systems that are structured workers effort and performance could be an answer to most of the labor unrest, low morale and commitment of some workers in Ghana.

Given the preponderance of vocal alternative viewpoints (e.g., Kohn, 1993; Pfeffer, 1998; Red, 2009), the indication is enormous; reward has dominant reinforcement and classifying effects (Gerhart \& Rynes, 2003; Jenkins et al., 1998). Compensation can shape employee 
behavior, create positive influences in the minds of the employees about the organization and lead to organizational effectiveness.

Employees may be empowered by a fair remuneration plan, decreasing the goal of searching for alternative work and turnover (Wanous, 1974; Shi, 1991)

Traditional compensation move from skills to financial incentives to non-financial incentives, from foreign to local, from constant to float, from integrated to separate, and from specific rewards to co-ordinate incentives, and record service to results (Chen \& Hsieh, 2006).Total rewards is the current trend in most organizations as they seek to motivate employees to give off their best.

Organizations use various types of rewards systems in rewarding employees for their contributions to productivity. Total compensation, described as "the complete compensation strategy along with Both payment methods, rewards, benefits, facilities and inventory' (Milkovich \& Newman, 2002) have identified compensation documentation in a variety of forms, i.e. basic salary, bonuses, share options, benefits (Dreher et al., 1988; Sanders \& Carpenter, 1998).There are various rewards programs for each organization; however, total rewards are not just wages and wellbeing (Zingheim \& Schuster, 2006). It is a detailed integrated program consisting of all rewards components (Armstrong \& Stephens, 2005).

Each organization has different rewards systems; however, total rewards are not merely the salary and welfare (Zingheim \& Schuster, 2006). It's a comprehensive unified program that consist all parts of rewards (Armstrong \& Stephens, 2005).

World at Work (2006) describes total reward as all the tools available to attract, inspire and retain workers for the organization and encompasses all that the employee feels to be relevant in the contractual relationship. Overall incentives give workers the opportunity to gain expertise and develop new skills that promote their future career (Ludlow \& Farrell, 2010).

According to Armstrong (2006), pay and benefits represent transaction-based benefits that are monetary and external in nature and are necessary for employing and retaining employees yet can be replicated easily by competitors. On the other hand, social incentives are non-monetary and increase the value of rewards.

Total rewards experience for many firms has highlighted the strategic incentive policy (Egan, 2011). Traditional design and procedures also lead to a static payment structure from the theoretical point of view, which does not effectively inspire workers and lead to low employee morale (Heneman \& Lebianc, 2001).

The benefits of total rewards are enormous and organizations use total rewards strategies to ensure best human resource practices are adhered to, organizations take measures relevant to staff development from the context of the advance of human resources, which would increase employee incentive to create positive mutual habits (Settoon et al., 1996).It can lead to changing employee behavior and attitudes positively towards organizations, incentives gratification and appraisal of workers to the corporate wellbeing system would have an significant effect on the assertiveness and actions of employees (Danehower \& Lust, 1996).

The compensation history has primarily concentrated on a restricted concept of reward, analyzing wage, both set in wages, salaries, flexible by schemes as rewards and incentives (Gerhart \& Rynes, 2003). The need to examine the concepts, measurements of pay mix has gained attention in recent years as it is believed that it could also contribute in improving job satisfaction and employee motivation and performance. 
Managers need to develop a range of effective ways to compensate workers to achieve the desired outcomes in order to enhance employee views of their compensation mix (Falola et al., 2014). It was also proposed that the extent of workers happiness with work and their willingness to stay with an enterprise is a result of the organization's pay packages and incentive scheme (Osibanjo et al., 2012).

As averred by Bamigbola \& Akaigbe (2016), it is a persistent and recurrent struggle for businesses to fully know what metrics lead to enhanced levels of behavioral intentions for their workers. Getting to know the types and levels of the compensation packages that most suit employees will help to improve the way employees perceive their compensation mix and make appropriate steps to improve their perception.

\section{Concept of Compensation Mix and its Applicability to the Ghanaian Situation}

Reward system is a challenging and sometimes multiplier process as stated by Gerhart \& Rynes (2003), perhaps the reason why most organizations in Ghana pay little attention to the mix different reward types offered, the measurements and evaluation of the reward systems. Existing literature on the concept of compensation mix is highly researched and applicable in the developing economies; however literature in a developing country perspective remains scanty as most research has focused on executive compensation mix. Most Ghanaian workers may be concerned with the salary and benefits offered by their organizations and the annual performance increases given and are unlikely going to ask questions on the mix of pay given. However depending on their demographics such as age in service in the organization may be interested in benefits such as pensions and mortgages.

The concept of total rewards must be exploited in the reward of workers since the emphasis on the holistic and all-encompassing nature of it will appeal to most workers can positively influence their perception and work outcomes.

Total compensation can be considered as 'financial and non-monetary return to employees in return for their time, expertise, energies and outputs' in terms of the variety of employee needs (World at Work, 2007, p. 4) both financially and non-financially, it considers reward holistically. In particular, wage and monetary-based benefits, Bussin et al., (2016) financial rewards relate to the financial needs of the individual. Non-financial incentives such as skills enhancement opportunities, career prospects and governance, corporate values, success and appreciation, working relationships, occupational protection and career-life balance (Armstrong, 2002; Thompson \& McHugh, 2002 \& World at Work, 2008).

Considering both financial and non- financial rewards in the compensation mix package could be the panacea to most people management issues in Ghana since it affords the employee the opportunity to determine the mix suitable to each employee.

As succinctly espoused by Anku-Tsede \& Kutin (2013) In order to inspire workers to gain a competitive advantage, most enterprises in Ghana generally place greater focus on conventional incentives such as invariably satisfiers and monetary in nature. At the value of non-benefits such as task stability, employee appreciation, job enhancement, career growth, job protection, and feeling of belongingness, compared to financial rewards, all of which have a connection and personal orientation to the job itself.

A concentration on financial rewards will likely lead to dissatisfaction on the part of most workers and depending on the preferences of the particular worker may lead to low performance and motivation as reiterated by Gneezy et al., (2011) that incentive strategies that rely mainly on financial incentives contribute to low motivation for workers. 
The need to concentrate on non-financial rewards has long been recognized by earlier researchers.

However, it is indicated that though the Ghanaian worker's desire to obtain a job in return for monetary survival advantages, financial benefits solely may not inherently inspire the workers to give up their best. ( Anku-Tsede \& Kutin, 2013)

The mix of reward types offered to the worker should be considered to ensure the objectives of these reward strategies lead to better employee engagement.

On the issue of compensation mix there is still need for the concept to be well understood by researchers and practitioners in order to inform compensation policy decisions of companies. Incentive researches have concentrated on level (how much people are paid) and composition (the make-up of the different levels of reward).Compensation mix choices, i.e. the comparative percentages of each component making up the overall reward, have been less emphasized, (Chapman \& Kelleher, 2011).

Therefore, incentive mix decisions are largely guided by set legal and tax restrictions, along with pressure to adhere to other organizations' procedure or established recommended practice models (Chapman \& Kelliher, 2011). In addition, the conceptualization of the incentive mix remains a field requiring further research; reward mix conceptualization has essentially remained deficient, disregarding major components in the provision of incentives and less concrete non-financial rewards (Chapman \& Kelliher, 2011).

This assertion may also be reasons why the concept is less known and virtually given less emphasis in compensation policies of organizations in Ghana.

In developing countries like Ghana, most human resource practitioners and labor stakeholders are yet to come to terms with the concepts of reward mix and it applicability in terms of using it to impact compensation policy. Considering the fact that most studies on reward mix have been inconclusive and this may have contributed to the low applicability of the concept as noted by earlier researchers.

Schuler and Jackson (1987) recognized sthe correlation among employee compensation, morale and job fulfillment is purposefully essential for the success of enterprises and is a key success factor building specific and vibrant skills set for companies (Khalid et al., 2011).

Thus, if Ghanaian companies hope to gain competitive advantage they must concentrate on reward, motivation and job satisfaction and classify a versatile combination of incentives that include option and are ideally targeted for workers (Anku-Tsede \& Kutin, 2013).

Different reward types and mix are used in organizations to appeal, encourage and maintain employees and to create a positive perception about the organization, serve as a motivational tool for employees who due to individual preferences may prefer particular rewards types in relation to others.

Though very some few methods exist and most strive to reflect the pay mix of companies, variations in understanding of the concept and interpretation prevent the significance and effects of the pay mix from being replicated (Yanadori et al., 2002).

The current situation is where standardized salaries paid to employees based on salary pay levels without considering the mix of the pay and whether it satisfies individual needs and preferences, this ensures internal equity as people doing the same kind of job are most likely to be paid equal. The annual performance appraissals may ensure differences in salary raises based on the employee performance pay increase. It was noted that employees in private sector organizations have a voice through the labor unions in terms of salary and benefits, however they do not determine the mix of the pay levels neither do they have a voice in suggesting what their preferences are in terms of the compensation mix. 
Most practitioners of labor management in Ghana believe the concept must be embraced and in designing compensation packages for workers, the particular needs and preferences of the worker in terms of their demographics must be considered in determining the compensation mix.

However the challenges that labor stakeholders envisage in considering compensation mix in salary administration is how to conceptualize and measure it to the satisfaction of employees. They believe practitioners may require training and supervision to ensure fairness and internal equity in its administration.

Organizations have various reward types and may engage various mixtures of generational cohorts including part time and full time workers, the preferred benefits mix approach aims to attract, inspire, hire and maintain their staff to achieve its strategic goals and also impact positively on employee perception so as to ensure the right behaviors necessary for organizational success is assured.

The following strategies if adopted could improve employee pay management in order to improve employee perception of their compensation mix and work behavior.

- Discussing with labor unions the compensation mix and how to integrate this in the compensation package of collective bargaining agreement where the proportion of fixed to variable rewards will be determine and agreed upon.

- The companies make a conscious effort to engage the different mixes of generations of workers employed to solicit, their views on their preferences and perception of the compensation mix prior to implementation.

- Companies should develop a framework for administering compensation where the individual preferences and needs could be well documented to serve as a guide in pay administration.

- The need for a deeper understanding of the concepts and measurements of compensation mix, having the right proportions of fixed income, benefits and relational returns in the compensation mix.

\section{Conclusion}

Employees are also given a lot of flexibility as to how precisely their employee benefits should be (Griffin, 1999). The employer sets the total value, so it is for workers to decide their preference for various types of rewards (Torrington et al, 2005). The same view was held by (Armstrong, 2006; Griffin, 1999) when they claimed that equity compensation structures permit workers to decide on the composition of their compensation plan according to their needs within certain limits.

This view is perhaps what most Ghanaian companies may want to adopt in their compensation policy to give employees the choice and a voice in deciding on how the compensation mix package should be. As emphasized by White \& Druker (2013) Effective reward programs are designed to augment and improve business model. Such an approach if adopted could lead to more engaged workers and the attainment of business strategies. Ghanaian organizations, To guarantee adequate longevity of workers, it is necessary to take measures to incorporate incentive choices that supports effective, successful as well as hardworking employees as succinctly espoused by (Bussin et al., 2016). 


\section{Acknowledgements \\ Competing Interests}

In writing this paper, the writers confirm that they have no competing interest that could have improperly impacted them.

\section{Contributions from Author}

The principal investigator was R.S.B., who was in charge of the design, implementation and the writing of the article. The co-author contributed in editing and article writing.

\section{References}

Anderson, M. C., Banker, D. R., \& Ravindran, S. (2000). Executive compensation in the information technology industry. Management Science 46(4) 530-547.

Anku-Tsede, O., \& Kutin, E. (2013). Total Reward Concept: A Key Motivational Tool for Corporate Ghana. Business and Economic Research, 3(2).

Armstrong, M., \& Stephens, T. (2005). Handbook of Employee Reward Management and Practice. Kogan Page,London.

Armstrong, M. (2006), A Handbook of Human Resource Management Practice. (10th ed.), Kogan Page Limited, London.

Armstrong, M., \& Murlis, H. (2007). Reward Management: A Handbook of Remuneration Strategy and Practice. London, Kogan Page Limited

Armstrong, M. (2009). Handbook of human resource management practice, $11^{\text {th }}$ (ed.) Kogan Page, London

Armstrong, M., Brown, D., \& Peter Reilly (2011). Increasing the effectiveness of reward management: an evidence-based approach. Institute for Employment Studies, London, UK Vol. 40 No. 7, pp. 1651-82. Employee Relations Vol. 33 No. 2, 2011 pp. 106-120

Armstrong, M., \& Murlis, H. (2007), Reward management: A handbook of remuneration strategy and practice, 5th ed, Kogan Page Limited, London

Balkin, D., \& Gomez-Mejia, L. (1990). Matching compensation and organizational strategies. Strategic Management Journal 11: 153-169.

Banjoko, S. A. (2006). Managing corporate reward system. Lagos; Pumark Nigeria Limited.

Beatty, R. P., \& Zajac, E. J. (1994). Managerial incentives, monitoring, and risk bearing: A study of executive compensation, ownership, and board structure in initial public offerings. Administrative Science Quarterly, 39: 313-353.

Bevan, S. (2006), New Realism in Reward Strategy, e-reward, Stockport.

Bloom, M., \& Milkovich, G. T. (1998). Relationships among risk, incentive pay, and organizational performance. Academy of Management Journal, 41: 283-297.

Burke, L. A., \& Hsieh, C. (2006). "Optimizing fixed and variable compensation costs for employee productivity", International Journal of Productivity and Performance Management, Vol. 55 Nos 1/2, pp. 155-62

Bussin, M., \& Toerien, W. C. (2015). Influence of reward preferences in attracting, retaining, and motivating knowledge workers in South African information technology companies. Acta Commercii, 15(1), Art. \#290, 1-13. https://doi.org/10.4102/ac.v15i1.290

Chapman, J., \& Kelliher, C. (2011). Influences on reward mix determination: Reward consultants" perspectives. Employee Relations, vol. 33, no. 2, pp 121-139.

Chen, H. M., \& Hsieh, Y. H. (2006). Key Trends of the Total Reward System in 21st Century. Compensation and Benefits Review, 38(8), 64-70.

http://dx.doi.org/10.1177/0886368706292542. 
Dalvi, M., \& Ebrahimi, H. (2013). Investigating the Effects of Reward on the Cooperation in the Sale and Marketing Department from Managers' Perspective (Isfahan Food industries Case Study). International Journal of Academic Research in Business and Social sciences, 3 (1), 144-153.

Danehower, C., \& Lust, J. A. (1996). How aware are employees of their benefits? Findings from two companies. Benefits Quarterly, 12(4), 57.

Datta, P. (2012). An Applied Organizational Rewards Distribution System. Management Decision, 50 (3), 479-501

Diekmann, N. (2015) "Understanding Pay: Perceptions, Communication and Impact in ForProfit Organizations" (2015). Education Doctoral Dissertations in Leadership. 65. https://ir.stthomas.edu/caps_ed_lead_docdiss/65

Dreher, G. F., Ash, R. A., \& Bretz, R. D. (1988). Benefit coverage and employee cost: Critical factors in explaining compensation satisfaction. Personnel Psychology, 41: 237-254.

Dunn, P., He, Z., \& Trabelsi, S. (2018). Executive compensation and compensation risk: evidence from technology firms www.emeraldinsight.com/0268-6902.htm.

Egan, J. (2011). Strategic rewards and total rewards. The Chartered Institute of Personnel and Development. Retrieved March 12, from http://www.cipd.co.uk

Elvira, M. M. (2001). "Pay me now or pay me later: analyzing the relationship between bonus and promotion incentives", Work and Occupations, Vol. 28 No. 3, pp. 346-70.

Falola, H. O., Ibidunni, A. S., \& Olokundun, A. M. (2014). Incentives packages and employees' attitudes to work: a study of selected government parastatals in Ogun State, SouthWest, Nigeria, International Journal of Research in Business and Social Science IJRBS, 3(1), 2147-4478.

Eisenhardt, K. M. (1988). Agency-and institutional-theory explanations: The case of retail sales compensation. Academy of Management Journal, 31: 488-511.

Foot, M., Hook, C., \&Jenkins, A (2016) Introducing Human Resource Management. $7^{\text {th }}$ ed.Pearson Education Limited.

Gerhart, B., \& Rynes, S. (2003). Compensation: Theory, Evidence, and Strategic Implications. Sage Publications

Gupta, N., \& Shaw, J. D. (2015). Employee compensation: The neglected area of HRM research. Human Resource Management Review, 24, 1-4. doi:10.1016/j.hrmr.2013.08.007

Gerhart, B., \& Milkovich, G. T. (1990). Organizational differences in managerial compensation and financial performance. Academy of Management Journal, 33: 663-691.

Gomez-Mejia, L. R., Tosi, H., \& Hinkin, T. (1987). Managerial control, performance, and executive compensation. Academy of Management Journal, 30: 51-70.

Gomez-Mejia, L. R. (1992). Structure and Process of Diversification, Compensation Strategy, and Firm Performance, Strategic Management Journal, vol.13, pp.381.

Gupta, N., \& Shaw, J. D. (2015). Employee compensation: The neglected area of HRM research. Human Resource Management Review, 24, 1-4. doi:10.1016/j.hrmr.2013.08.007.

Hartman, D. (2014). Types of finance-rewards and incentives, 2011, Available at www.eHowmoney.com accessed on the 4th of May.

Heneman, F. (2003). Behavioral management and task performance in organizations: Conceptual background, meta-analysis and test of alternative models. Pers. Psychol. 56, $1-10$ 
Idemobi, E., Onyeizugbe, I., Chinedu, U., \& Akpunonu, E. O. (2011). Compensation management as a tool for improving organizational performance in the public sectors, International Journal of Human Resource Management, 1(1), 109-120

Ivancevich, J. M. (2004). Human resource management, New York: McGraw-Hill/Irwin Jiang, Z., Xiao, Q., Qi, H., \& Xiao, L. (2009). Total rewards strategy going with the trend of the times. International Journal of Business and Management, 4(11) 177-183

Judge, T. A., \& Hulin, C. L. (1993). Job satisfaction as a reflection of disposition: A multiple source casual analysis. Org. Behav. Hum. Deci. Proc. 56, 388-421.

Kwenin, D. O., Muathe, S., \& Nzulwa, R. (2013) The Influence of Employee Rewards, Human Resource Policies and Job Satisfaction on the Retention of Employees in Vodafone Ghana Limited. European Journal of Business and Management www.iiste.org ISSN 2222-1905 (Paper) ISSN 2222-2839 (Online) Vol.5, No.12, 2013

Naukrihub, C. (2007). Performance management system (accessed Oct, 2016$).$

Nickerson, J. A., \& Zenger, T. R. (2008). Envy, comparison costs, and the economic theory of the firm. Strategic Management Journal 29(13): 1429-1449. N.2010-03, Centre for Decision Research and Experimental Economics at the University of Nottingham, Nottingham, U.K.

Nienaber, R., Bussin, M., \& Henn, C. (2011). The relationship between personality types and reward preferences. Acta Commercii, 11(2), 1-21.

https://doi.org/10.4102/ac.v11i2.153

Obisi, C. (1996). Personnel management. Freeman Publications, Ibadan, Nigeria.

Olusoji, G., Olashile, B. B., \& Akaighe, G. (2016) Effect Of Reward And Compensation On Employee Loyalty And Performance In Asset Management Corporation Of Nigerian (Amcon) International Journal of Management and Development Studies, 2016, 2(2), 49-60.

Oshagbemi, T. (2000). Correlates of pay satisfaction in higher education. The International Journal of .Education Managment. 14(1),31-39.

Osibanjo, A. O., Abiodun, A. J. \& Fadugba, A. O. (2012). Executive perception of the impact of flexitime on organisational performance: evidence from the Nigeria Private Sector, International Journal of Applied Behavioural Economics, IJABE, 1(3), 16-27.

Patnaik, B. C. M., \& Padhi, P. C. (2012) compensation management: a theoretical preview TRANS Asian Journal of Marketing \& Management Research Vol.1 Issue 1, September 2012, ISSN (online) TRANS Asian Research Journals http://www.tarj.in.

Pfeffer, J. (1998), The Human Equation: Building Profits By Putting People First. Harvard Business School Press: Boston, USA.

Quartey, S. H., \& Attiogbe, E. J. (2013). Is there a link between compensation and job performance in the Ghana Police? African Journal of Business Management, 7(44), 4398-4406

Samad, S. (2007). Assessing the effects of job satisfaction and psychological contract on organizational commitment among employees in Malaysian SMEs. The 4th SMES in A Global Economy Conference

Sanders, W. G., \& Carpenter, M. A. (1998). Internationalization and firm governance: The role of CEO compensation, top team composition, and board structure. Academy of Management Journal, 41: 158-178.

Schlechter, A., Thompson, N., \& Bussin, M. (2015). Attractiveness of non-financial rewards for prospective knowledge workers. Employee Relations, 37(3), 274-295. http://dx.doi.org/10.1108/ER-06-2014-0077. 
Schuler, R., \& Jackson, S. (1987). Linking competitive strategies and human resource management practices. Academy of Management Executive, 1(3), pp. 207-219.

Khalid, K., Salim, H. M. \& Loke, S. P. (2011). The impact of rewards and motivation on job satisfaction in water utility industry. International Conference on Financial Management and Economics, 11, pp. 35-41.

Korir, I., \& Kipkebut, D. (2016). The Effect of Reward Management on Employees Commitment in the Universities in Nakuru County-Kenya. Journal of Human Resource Management. Vol. 4, No. 4, 2016, pp. 37-48. doi: 10.11648/j.jhrm.20160404.12.

Ludlow, A., \& Farrell, A. (2010). Making total rewards work. Strategic HR Review, 9(6), 49.

Pfeffer, J. (1998), The Human Equation: Building Profits by Putting People First, Harvard Business School, Boston, MA.

Tremblay, M., Cote, J., \& Balkin, D.B. (2003). “Explaining sales pay strategy using agency, transaction cost and resource dependence theories", The Journal of Management Studies,

Werner, A. (2001). Motivation in human resource management, Cape Town: Oxford University Press.

Werner, S., \& Tosi, H. L. (1995). Other people's money: The effect of ownership on compensation strategy and managerial pay. Academy of Management Journal, 38: 1672-1691.

Westphal, J. D. (1999). Collaboration in the boardroom: Behavioral and performance consequences of CEO-board social ties. Academy of Management Journal, 42: 7-24.

Westphal, J. D., \& Zajac, E. J. (1995). Who shall govern? CEO/board power, demographic similarity, and new director selection. Administrative Science Quarterly, 40:60-83.

Worldat Work. (2006), Total Rewards Concept and Model. Available at www.worldatwork.org. Yamoah, E. E. (2013). Relationship between compensation and employee productivity, Singaporean Journal of Business Economics, and Management Studies, 2(1), 110-114

Yanadori, Y., Sturman, M. C., Milkovich, G. T. \& Marler, J. H. (2002). "Organizational Pay Mix: The Implications of Various Theoretical Perspectives for the Conceptualization and Measurement of Individual Pay Components", CAHRS Working Paper, vol. 2, no. Ithaca, NY: Cornell University.

Zingheim, P. K., \& Schuster, J. R. (2003). Competencies and rewards: substance or just style? Compensation \& Benefits Review, 35(5), 40-44.

http://dx.doi.org/10.1177/0886368703256932 